\title{
High variation in repetitive DNA fragment length for white spot syndrome virus (WSSV) isolates in Thailand
}

\author{
Chainarong Wongteerasupaya ${ }^{1}$, Paranee Pungchai ${ }^{2}$, Boonsirm Withyachumnarnkul ${ }^{3}$, \\ Vichai Boonsaeng ${ }^{3}$, Sakol Panyim ${ }^{3}$, T. W. Flegel ${ }^{3, *}$, Peter J. Walker ${ }^{4}$ \\ ${ }^{1}$ Department of Biochemistry, Faculty of Medicine, and ${ }^{2}$ Department of Biology, Faculty of Science Srinakharinwirot University, \\ Sukhumvit 23 Road, Bangkok 10110, Thailand \\ ${ }^{3}$ Centex Shrimp, Chalerm Prakiat Building, Faculty of Science, Mahidol University, Rama 6 Road, Bangkok 10400, Thailand \\ ${ }^{4}$ CSIRO Livestock Industries, Long Pocket Laboratory, Indooroopilly, Brisbane, Queensland 4068, Australia
}

\begin{abstract}
White spot syndrome virus (WSSV) presently causes the most serious losses to shrimp farmers worldwide. Earlier reports of high DNA sequence homology among isolates from widely separated geographical regions suggested that a single virus was the cause. However, we have found surprisingly high variation in the number of $54 \mathrm{bp}$ DNA repeats in ORF94 (GenBank AF369029) from 55 shrimp ponds (65 shrimp samples) experiencing WSSV outbreaks in Thailand in 2000 and 2002. These were detected by PCR amplification using primers ORF94-F and ORF94-R flanking the repeat region. Altogether, 12 different repeat groups were found (from 6 to 20 repeats) with 8 repeats being most frequent (about $32 \%$ ). Extracts prepared from individual shrimp in the same outbreak pond belonged to the same repeat group while those collected at the same time from separate WSSV outbreak ponds, or from the same ponds at different times, usually belonged to different repeat groups. This suggested that different outbreaks were caused by different WSSV isolates. In contrast to the highly variable numbers of repeats, sequence variation within the repeat region was confined to either $\mathrm{T}$ or $\mathrm{G}$ at Position 36. These variations may be useful for epidemiological studies on the local and global movement of WSSV, since there is high variation in the number of repeats (good for local studies) but little sequence change (good for global studies).
\end{abstract}

KEY WORDS: WSSV - DNA sequence variation - Tandem DNA repeat

Resale or republication not permitted without written consent of the publisher

High losses from white spot syndrome virus (WSSV) were first reported from cultivated shrimp ponds in China, 1993, but these subsequently spread to most major shrimp cultivation areas globally in succeeding years (Flegel 1997, Lightner 1996). It is currently the most serious viral pathogen of shrimp worldwide, with estimated losses in production amounting to several hundred million US dollars per year in Asia alone (Flegel \& Alday-Sanz 1998). Characterization of WSSV has shown that it is a tailed, rod-shaped, doublestranded DNA virus (Wongteerasupaya et al. 1995, Lightner 1996) with a very large genome in the order of $300 \mathrm{~kb}$ (van Hulten et al. 2001). Since the genome has no significant homology to any known virus, it has been assigned to a new viral family (Nimaviridae) and a new viral genus (Whispovirus) (van Hulten et al. 2001; www.ncbi.nlm.nih.gov/ICTVdb/Ictv/index.htm).

Sequence comparison of relatively small regions of the total genome have shown very little variation in widely separated geographical isolates of WSSV (Lo et al. 1999, Wang et al. 2000). This high uniformity in DNA sequences suggests that a single virus species is responsible for the worldwide outbreaks caused by WSSV and has also made it difficult to trace movements of the virus with any degree of certainty. Recent publications (Tsai et al. 2000, van Hulten et al. 2000) and deposition of full WSSV genome sequences at GenBank (AF369029 from Thailand hereinafter called WSSV-Th, AF440570 from Taiwan hereinafter called WSSV-Tw, and AF332093 from China hereinafter called WSSV-Ch) have revealed the presence of several tandemly repeated DNA sequences. For example, ORF94 in WSSV-Th (van Hulten et al. 2001) contains 6 tandem repeats of a $54 \mathrm{bp}$ sequence (hereinafter called ORF94-54) as does WSSV-Tw (ORF WSSV234). By contrast WSSV-Ch (ORF WSV178) has 12 repeats. The only sequence variation within the repeat region is alternation of $\mathrm{G}$ or $\mathrm{T}$ at Position 36 of the repeat. We considered that this repeat region might be useful for comparison of WSSV from shrimp culture ponds experiencing white spot disease outbreaks. Our strategy 
Table 1. Source, date and number of samples collected for the study

\begin{tabular}{|c|c|c|c|}
\hline Province & Location & Date & No. of ponds \\
\hline Chantaburi & SE coast, Gulf of Thailand & 25 to 29 Jan 2002 & 6 \\
\hline Chacheongsao & Central Thailand near Bangkok & $\begin{array}{l}29 \text { Sep to } 10 \text { Oct } 2000 \\
1 \text { to } 30 \text { Jan } 2002\end{array}$ & $\begin{array}{r}8 \\
17\end{array}$ \\
\hline Chumporn & Mid-SW coast, Gulf of Thailand & $\begin{array}{l}11 \text { to } 29 \text { Nov } 2000 \\
28 \text { Nov } 2002\end{array}$ & $\begin{array}{l}4 \\
1\end{array}$ \\
\hline Surat Thani & Lower SW coast, Gulf of Thailand & $\begin{array}{l}9 \text { and } 24 \text { Oct } 2000 \\
26 \text { Nov to } 13 \text { Dec } 2002\end{array}$ & $\begin{array}{r}11 \\
6\end{array}$ \\
\hline Nakornsrithumarat & Lower SW coast, Gulf of Thailand & 5 Sep to 13 Oct 2000 & 2 \\
\hline Total & & & 55 \\
\hline
\end{tabular}

was to construct PCR primers bracketing the multiple repeat region of the ribonuclease reductase gene of WSSV, to use these with template DNA extracted from a variety of WSSV-infected Thai shrimp, and to sequence any PCR products for possible variation. We found wide variation in the number of tandem repeats but little change in sequence amongst the isolates tested.

Materials and methods. Shrimp specimens: A total of 65 specimens of shrimp were collected from 55 Thai shrimp ponds experiencing outbreaks of white spot disease (WSD) over the interval October 2000 to January 2002. Pleopods from live, moribund shrimp showing gross signs of WSD were clipped with scissors cleaned in alcohol and placed directly in $95 \%$ ethanol for transport to the laboratory (volume of ethanol 10 times more than tissue placed in it). Farming areas included in the study were Chuntaburi Province on the east coast of the Gulf of Thailand, Chacheongsao Province in central Thailand and Surat Thani and Chumporn provinces in the mid-south on the west coast of the Gulf of Thailand (Table 1).

Nucleic acid purification: Infected tissues were homogenized in TN buffer $(20 \mathrm{mM}$ Tris-HCl, $400 \mathrm{mM}$ $\mathrm{NaCl}, \mathrm{pH}$ 7.4). After centrifugation at $2000 \times g$ for 10 min, DNA was isolated by treatment with Proteinase $\mathrm{K}\left(0.2 \mathrm{mg} \mathrm{ml}^{-1}\right)$ and sarkosyl $(1 \%)$ at $45^{\circ} \mathrm{C}$ for 2 to $4 \mathrm{~h}$ followed by phenol-chloroform extraction (Sambrook \& Russel 2001).

PCR reactions: The primers used were derived from ORF94 of WSSV as part of the total genome of WSSVTh (van Hulten et al. 2001) and designed to act as upstream and downstream brackets to 6 tandem repeats of a $54 \mathrm{bp}$ sequence (ORF94-54). The primers were ORF94-F (5'-TCT ACT CGA GGA GGT GAC GAC-3') and ORF94-R (5'-AGC AGG TGT GTA CAC ATT TCA TG-3'). For the PCR, 10 ng DNA template and $30 \mathrm{pmol}$ each primer were added to $50 \mu \mathrm{l}$ reaction mixture containing $10 \mathrm{mM}$ Tris- $\mathrm{HCl}, \mathrm{pH} 8.3,50 \mathrm{mM}$ $\mathrm{KCl}, 1.5 \mathrm{mM} \mathrm{MgCl}_{2}, 200 \mu \mathrm{M}$ each dATP, dTTP, dCTP
Table 2. Number and frequency of ORF94 repeats found in PCR products from DNA extracts of 65 Thai shrimp samples taken from 55 white spot syndrome virus (WSSV) outbreak ponds

\begin{tabular}{|lcccc|}
\hline $\begin{array}{l}\text { No. of } \\
\text { repeats }\end{array}$ & $\begin{array}{c}\text { Amplicon } \\
\text { size (bp) }\end{array}$ & $\begin{array}{r}\text { No. of } \\
\text { shrimp }\end{array}$ & $\begin{array}{r}\text { No. of } \\
\text { ponds }\end{array}$ & $\begin{array}{c}\text { Frequency } \\
\text { for ponds }\end{array}$ \\
\hline 6 & 506 & 9 & 8 & 0.14 \\
7 & 560 & 8 & 6 & 0.10 \\
8 & 614 & 19 & 18 & 0.32 \\
9 & 668 & 10 & 8 & 0.14 \\
10 & 722 & 5 & 3 & 0.05 \\
11 & 776 & 1 & 1 & 0.02 \\
12 & 830 & 4 & 4 & 0.07 \\
13 & & - & - & - \\
14 & 938 & 2 & 2 & 0.04 \\
15 & 992 & 1 & 1 & 0.02 \\
16 & & - & & - \\
17 & 1100 & 2 & 2 & 0.04 \\
18 & & - & - & - \\
19 & 1208 & 3 & 1 & 0.02 \\
20 & 1262 & 1 & 1 & 0.02 \\
Total & & 65 & 55 & - \\
\hline
\end{tabular}

and dGTP, 2.5 U TaqDNA polymerase Gibco-BRL (Life Technologies). The mixture was incubated in a thermal cycler using 35 cycles of $94^{\circ} \mathrm{C}$ for $1 \mathrm{~min}, 52^{\circ} \mathrm{C}$ for $1 \mathrm{~min}$ and $72^{\circ} \mathrm{C}$ for $1 \mathrm{~min}$, and a final elongation step at $72^{\circ} \mathrm{C}$ for $10 \mathrm{~min}$. The PCR products were resolved by $1.2 \%$ agarose gel electrophresis (Nusieve 3:1) at $5 \mathrm{~V} \mathrm{~cm}^{-1}$.

Sequence analysis: PCR amplicons were purified from agarose gels using a QIA quick Gel Extraction Kit (QIAGEN) and were sequenced using Thermo Sequence $^{\mathrm{TM}}$ (Amersham) and an Automated ABI model 377 Sequencing system (Applied Biosystem). Sequence alignment and estimation of sequence identity were conducted using Clustal W software.

Results and discussion. A preliminary test of 3 shrimp each from 4 outbreak ponds (not shown) indicated that multiple shrimp specimens from the same pond would give the same result for ORF94 repeat group, although larger samples would be needed to 
Table 3. Pattern of ORF94 repeat groups for WSSV outbreak ponds sampled in 2000 and 2002

\begin{tabular}{|c|c|c|c|c|c|c|c|c|c|}
\hline \multirow{2}{*}{$\begin{array}{l}\text { No of } \\
\text { repeats }\end{array}$} & \multicolumn{4}{|c|}{2000} & \multicolumn{4}{|c|}{2002} & \multirow{2}{*}{ Total } \\
\hline & $\begin{array}{l}\text { Surat } \\
\text { Thani }\end{array}$ & $\begin{array}{l}\text { Chum- } \\
\text { porn }\end{array}$ & $\begin{array}{c}\text { Chat- } \\
\text { cheongsao }\end{array}$ & $\begin{array}{c}\text { Nakorn- } \\
\text { srithamarat }\end{array}$ & $\begin{array}{l}\text { Surat } \\
\text { Thani }\end{array}$ & $\begin{array}{l}\text { Chum- } \\
\text { porn }\end{array}$ & $\begin{array}{c}\text { Chat- } \\
\text { cheongsao }\end{array}$ & $\begin{array}{c}\text { Chanta- } \\
\text { buri }\end{array}$ & \\
\hline 6 & 4 & 1 & & & & & 3 & & 8 \\
\hline 7 & & 1 & & & 1 & & 4 & & 6 \\
\hline 8 & 2 & 1 & 8 & & 2 & & 5 & & 18 \\
\hline 9 & 5 & 1 & & & & 1 & 1 & & 8 \\
\hline 10 & & & & 2 & & & 1 & & 3 \\
\hline 11 & & & & & & & & 1 & 1 \\
\hline 12 & & & & & 1 & & 2 & 1 & 4 \\
\hline 14 & & & & & & & & 2 & 2 \\
\hline 15 & & & & & & & 1 & & 1 \\
\hline 17 & & & & & 1 & & & 1 & 2 \\
\hline 19 & & & $5^{\mathrm{a}}$ & & 1 & & & & 1 \\
\hline 20 & & & & & & & & 1 & 1 \\
\hline Total & 11 & 4 & 8 & 2 & 6 & 1 & 17 & 6 & 55 \\
\hline
\end{tabular}

test this assumption rigorously. Based on this test, we assumed that each pond outbreak was caused by a single WSSV type, and only 1 to 3 individual shrimp were tested from each pond. The DNA extracts from 65 samples of WSSV-infected shrimp from 55 ponds gave a variety of amplicons using the primers ORF94-F and ORF94-R (Table 2), suggesting differences in the number of repeats from pond to pond. An example gel for fragments representing 6 to 11 repeats is shown in Fig. 1. The most frequently encountered number of ORF94-54 repeats was 8, but the range was 6 to 20 . The GenBank records for WSSV-Th and WSSV-Tw (6 repeats) and WSSV-Ch (12 repeats) fell within this range. For the sake of explanation, we numbered these repeats regions ORF94-1 to ORF94-20, realizing that there were no ORF94-13, -16 and -18 repeats.

When comparing the number of ORF94 repeats found in samples from various shrimp farming areas (Table 3), there was no particular pattern, except in 2000 for Chacheongsao, where ORF94-8 dominated and Surat Thani, where ORF94-9 dominated. Also, the Chacheongsao samples gave 2 PCR amplicons, a strong one for ORF94-8 and a lighter one for ORF9419, possibly indicating infections with 2 strains of WSSV. Alternatively, it could have been a non-specific amplification product, although that would appear to be unlikely considering that 2 amplicons occurred in only 5 of the 8 shrimp tested (i.e. not all) and that no double amplicons occurred only in this sample. However, PCR product sequencing would be necessary to resolve this issue. In addition to differences in repeat pattern between ponds and areas, the pattern of repeats for Chacheongsao in 2000 and 2002 also differed (Table 3).
Sequencing several of the fragments confirmed the presence of the $54 \mathrm{bp}$ tandem repeat identical to that in WSSV-Th, WSSV-Tw and WSSV-Ch at GenBank, including variation in an alternate $\mathrm{T}$ or $\mathrm{G}$ at Position 36 (Table 4). In the initial repeat (ORF94-1), T at Position 36 was invariant in all the sequenced fragments and in WSSV-Th, WSSV-Tw and WSSV-Ch. T was also invariant for ORF94-2, except for G found in WSSV-Th (Table 4). Discounting ORF94-1 and ORF94-2, where T was overwhelmingly dominant, the number of $\mathrm{T}$ (24) and $G(22)$ was almost equal for the remaining repeats, although distribution amongst the repeats varied (Table 4).

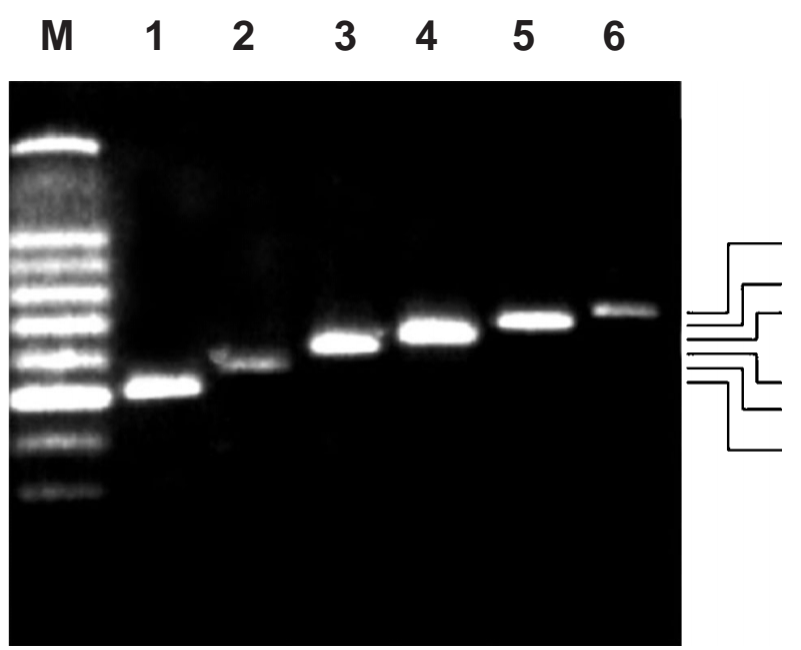

Fig. 1. Example agarose gel showing PCR amplification products for 6 (Lane 1) to 11 (Lane 6) ORF94 repeats 
Table 4. Summary of substitutions found at Position 36 in sequenced ORF94 tandem repeat regions of selected amplicons from Thai shrimp samples from Surat Thani (Surat) and Chumpol (Chum), compared to GenBank references for white spot syndrome virus (WSSV) in Taiwan, China and Thailand (WSSV-Tw, -Ch and -Th) with 6 and 12 ORF94 repeats

\begin{tabular}{|c|c|c|c|c|c|c|c|c|c|c|c|c|}
\hline \multirow[t]{2}{*}{ Isolate } & \multicolumn{12}{|c|}{ ORF94 repeat number } \\
\hline & 1 & 2 & 3 & 4 & 5 & 6 & 7 & 8 & 9 & 10 & 11 & 12 \\
\hline Surat \#1 & $\mathrm{T}$ & $\mathrm{T}$ & $\mathrm{T}$ & $\mathrm{T}$ & $\mathrm{G}$ & $\mathrm{T}$ & $\mathrm{T}$ & $\mathrm{G}$ & $\mathrm{T}$ & & & \\
\hline WSSV-Tw & $\mathrm{T}$ & $\mathrm{T}$ & $\mathrm{T}$ & G & $\mathrm{T}$ & $\mathrm{T}$ & & & & & & \\
\hline Chum \#2 & $\mathrm{T}$ & $\mathrm{T}$ & $\mathrm{T}$ & G & $\mathrm{T}$ & G & $\mathrm{T}$ & & & & & \\
\hline Chum \#4 & $\mathrm{T}$ & $\mathrm{T}$ & $\mathrm{T}$ & G & G & G & & & & & & \\
\hline Surat \#2 & $\mathrm{T}$ & $\mathrm{T}$ & G & $\mathrm{T}$ & $\mathrm{T}$ & G & G & $\mathrm{T}$ & & & & \\
\hline Chum \#3 & $\mathrm{T}$ & $\mathrm{T}$ & G & $\mathrm{T}$ & $\mathrm{T}$ & G & G & $\mathrm{T}$ & & & & \\
\hline WSSV-Ch & $\mathrm{T}$ & $\mathrm{T}$ & G & G & G & G & G & G & $\mathrm{T}$ & $\mathrm{T}$ & $\mathrm{T}$ & $\mathrm{T}$ \\
\hline WSSV-Th & $\mathrm{T}$ & G & G & G & $\mathrm{T}$ & $\mathrm{T}$ & & & & & & \\
\hline
\end{tabular}

Only 2 of the sequenced PCR products had identical numbers of repeats and identical sequences. These were Surat \#2 and Chum \#3, both with 8 repeats and derived from outbreak ponds in the interval October to November of 2000 (Table 4). The result suggested that these outbreaks were caused by the same type of WSSV, even though they were separated by several hundred kilometers. This being the case, it is unlikely that the ponds became infected by cross contamination. On the other hand, these 2 provinces are adjacent to each other and it is possible that the owners obtained post-larvae (PL) for stocking the ponds from the same source. Indeed, it is considered that WSSV infected PL are the main cause of WSD outbreaks in Thailand (Withyachumnarnkul 1999). A similar argument might apply to the Chacheongsao 2000 samples that also gave identical results with PCR products for ORF94 repeats of 8 and 19. By contrast, repeat groups from Chacheongsao in 2002 mostly differed from pond to pond, and also differed from those in 2000. Similarly, samples from Chum \#2, 3 and 4 collected at the same time in 2000 were all dissimilar in number of repeats and base pattern for Position 36. Perhaps these ponds used PL from different sources.

Other than Surat \#2 and Chum \#3, the variants in Table 4 show no obvious relationships. It is particularly interesting that WSSV-Th that originated from Thailand in 1996 (van Hulten et al. 2002) is markedly different from Chum \#4 (also 6 repeats) and all the Thai isolates we sequenced from 2000 and 2002. Perhaps this was because we sequenced only 1 isolate with 6 ORF94 repeats. Alternatively, it may indicate that changes have occurred in WSSV over time.

Obviously, the number of samples employed in this study was too small and taken at too intermittent intervals to make firm conclusions. However, they do show that the ORF94 repeat region has potential for use in epidemiological work with WSSV and may help in tracing its origin and spread. For example, it would be possible to use the method described herein to exam- ine captured broodstock to determine the prevalence of various WSSV types and to compare this with the prevalence of the types found in outbreak ponds. It would also be useful, if possible, to trace the sources of PL for the various ORF94 groups associated with outbreaks. This is generally not possible in Thailand due to fragmentation in the shrimp industry (i.e. unrelated broodstock suppliers, nauplius producers, PL producers and farmers), but it may be possible elsewhere or with a large integrated shrimp operation.

ORF94 lies together with other ORF of unknown function between genes for the large subunit (ORF92) and small subunit (ORF98) of WSSV ribonucleotide reductase (RR). In WSSV-Th, -Tw and -Ch, the open reading frames for ORF94 are maintained in the multiple repeats with the stop codon falling exactly at the end of the last repeat. There is no sequence variation amongst the 3 except for Position 36 of the repeat that leads to an alternate aspartic acid (D) or glutamic acid (E) in the putative protein sequences. The large variation in tandem repeats leads one to question whether ORF94 could produce a functional protein. Perhaps its function (if any) is related to DNA transcription or conformation. Given that all of the samples studied came from WSD outbreak ponds and showed variable ORF94 repeat length, it is not immediately obvious whether repeat length might be useful in identifying virulent strains of WSSV. However, the possibility should be explored.

Acknowledgements. The authors would like to thank the Thailand Research Fund, the National Center for Genetic Engineering and Biotechnology and the Australian Centre for International Agricultural Research for support to carry out this work.

\section{LITERATURE CITED}

Flegel TW (1997) Special topic review: major viral diseases of the black tiger prawn (Penaeus monodon) in Thailand. World J Microbiol Biotechnol 13:433-442

Flegel T, Alday-Sanz V (1998) The crisis in Asian shrimp 
aquaculture: current status and future needs. J Appl Ichthyol 14:269-273

Lightner DV (1996) A handbook of pathology and diagnostic procedures for diseases of penaeid shrimp. World Aquaculture Society, Baton Rouge, LA

Lo CF, Hsu HC, Tsai MF, Ho CH, Peng SE, Kou GH, Lightner DV (1999) Specific genomic DNA fragment analysis of different geographical clinical samples of shrimp white spot syndrome virus. Dis Aquat Org 35:175-185

Sambrook J, Russel DW (2001) Molecular cloning: a laboratory manual, 3rd edn. Cold Spring Harbor Laboratory, New York

Tsai MF, Lo CF, van Hulten MC, Tzeng HF and 6 others (2000) Transcriptional analysis of the ribonucleotide reductase genes of shrimp white spot syndrome virus. Virology 277:92-9

van Hulten MC, Tsai MF, Schipper CA, Lo CF, Kou GH, Vlak JM (2000) Analysis of a genomic segment of white spot syndrome virus of shrimp containing ribonucleotide reductase genes and repeat regions. J Gen Virol 81: $307-16$

Editorial responsibility: Carey Cunningham, Aberdeen, Scotland, UK van Hulten MC, Witteveldt J, Peters S, Kloosterboer N and 5 others (2001) The white spot syndrome virus DNA genome sequence. Virology 286:7-22

van Hulten MC, Reijns M, Vermeesch AM, Zandbergen F, Vlak JM (2002) Identification of VP19 and VP15 of white spot syndrome virus (WSSV) and glycosylation status of the WSSV major structural proteins. J Gen Virol 83: 257-65

Wang Q, Nunan LM, Lightner DV (2000) Identification of genomic variations among geographic isolates of white spot syndrome virus using restriction analysis and Southern blot hybridization. Dis Aquat Org 43:175-81

Withyachumnarnkul B (1999) Results from black tiger shrimp Penaeus monodon culture ponds stocked withpostlarvae PCR-positive or -negative for white-spot syndrome virus (WSSV). Dis Aquat Org 39:21-27

Wongteerasupaya C, Vickers JE, Sriurairatana S, Nash GL and 6 others (1995) A non-occluded, systemic baculovirus that occurs in the cells of ectodermal and mesodermal origin and causes high mortality in the black tiger prawn, Penaeus monodon. Dis Aquat Org 21:69-77

Submitted: August 21, 2002; Accepted: December 19, 2002 Proofs received from author(s): March 20, 2003 